\title{
Tolerance and sequestration of macroalgal chemical defenses by an Antarctic amphipod: a 'cheater' among mutualists
}

\author{
Margaret O. Amsler ${ }^{1}$, Charles D. Amsler ${ }^{1, *}$, Jacqueline L. von Salm ${ }^{2}$, \\ Craig F. Aumack ${ }^{1,3}$, James B. McClintock ${ }^{1}$, Ryan M. Young ${ }^{2}$, Bill J. Baker ${ }^{2}$ \\ ${ }^{1}$ Department of Biology, University of Alabama at Birmingham, Birmingham, Alabama 35294-1170, USA \\ ${ }^{2}$ Department of Chemistry, University of South Florida, Tampa, Florida 33620, USA \\ ${ }^{3}$ Present address: Department of Biology and Paleo Environment, Lamont-Doherty Earth Observatory, Palisades, \\ New York 10964-8000, USA
}

\begin{abstract}
Shallow-water communities along the western Antarctic Peninsula support forests of large, mostly chemically defended macroalgae and dense assemblages of macroalgal-associated amphipods, which are thought to exist together in a community-wide mutualism. The amphipods benefit the chemically defended macrophytes by consuming epiphytic algae and in turn benefit from an associational refuge from fish predation. In the present study, we document an exception to this pattern. The amphipod Paradexamine fissicauda is able to consume Plocamium cartilagineum and Picconiella plumosa, 2 species of sympatric, chemically defended red macroalgae. In previous studies, Plocamium cartilagineum was one of the most strongly deterrent algae in the community to multiple consumers, and was found here to be unpalatable to 5 other amphipod species which utilize it as a host in nature. Paradexamine fissicauda maintained on a diet of Plocamium cartilagineum for 2 mo were much less likely to be eaten by fish than Paradexamine fissicauda maintained on a red alga which does not elaborate chemical defenses, or than a different but morphologically similar sympatric amphipod species. Halogenated secondary metabolites produced by Plocamium cartilagineum were identified from tissues of the Paradexamine fissicauda that had eaten it but not those which had eaten the undefended red alga. This indicates that $P$. fissicauda is sequestering the potent chemical defenses of Plocamium cartilagineum for its own use.
\end{abstract}

KEY WORDS: Chemical defenses $\cdot$ Macroalgae $\cdot$ Amphipods $\cdot$ Sequestration $\cdot$ Antarctic ecology

\section{INTRODUCTION}

Small consumers, generally referred to as mesoherbivores or mesograzers, can have major influences on the composition and/or structure of marine communities (Brawley 1992, Heck \& Valentine 2006, Hillebrand 2009). This is particularly true with respect to macroalgal-associated amphipods (Duffy \& Hay 1991, 2000), which can have positive, negative, or neutral impacts on their host macrophytes (e.g. Duffy 1990, Buschmann \& Vergara 1993, Sotka et al. 1999, Poore et al. 2009).
Subtidal communities on hard substrata along the western Antarctic Peninsula support lush undersea macroalgal forests which are dominated by large, perennial brown algae (Wiencke \& Amsler 2012) and which support exceptionally dense amphipod assemblages (Richardson 1971, 1977, Huang et al. 2007, Aumack et al. 2011a). Estimated amphipod densities range up to tens to hundreds of thousands of amphipods per $\mathrm{m}^{2}$ of the bottom in pure stands of their preferred macroalgal hosts (Amsler et al. 2008). Most of the macroalgae, including all of the ecologically dominant taxa, are chemically defended from 
being consumed by both macrograzers and mesograzers (Amsler et al. 2005, 2008, 2009a, Aumack et al. 2010). Amphipods and other small marine grazers can benefit from associating with chemically defended macroalgae because the algae can provide a refuge from omnivorous macrograzers such as fish (Hay 1992, 1996). The relative mobility of the mesograzers, morphology of the macroalgae, and geographic location also are important (Holmlund et al. 1990, Duffy \& Hay 1994, Taylor \& Steinberg 2005, Zamzow et al. 2010). In some cases the mesograzers may be dietary specialists on the chemically defended macroalgae (Hay 1992). Such dietary specialists not only benefit from an associational refuge from predators but also in having an additional food source (cf. Sotka \& Whalen 2008).

Herbivore specialization on chemically defended prey necessitates a mechanism for tolerating the host's defensive secondary metabolites. Terrestrial herbivores are able to tolerate plant secondary metabolite defenses via a range of behavioral and metabolic processes (Després et al. 2007). There are far fewer studies of tolerance in marine herbivores, but the mechanisms of metabolic tolerance are similar (Sotka \& Whalen 2008). In both terrestrial and marine herbivores, metabolic tolerance of lipophilic metabolites is commonly mediated by all or part of a 3-phase pathway involving cytochrome P450s, glutathione S-transferases, and ATP binding cassette transporters, in which the metabolites are made more hydrophilic and then isolated into vesicles or excreted (reviewed by Karban \& Agrawal 2002, Sorensen et al. 2006, Després et al. 2007, Sotka \& Whalen 2008).

In addition to tolerating prey chemical defenses, some terrestrial arthropods (insects, particularly in the Coleoptera and Lepidoptera) and vertebrates (primarily amphibians, reptiles, and birds) are able sequester chemical defenses from prey organisms within their tissues for use as defenses against their own predators (Blum 1983, Nishida 2002, Opitz \& Muller 2009, Savitzky et al. 2012). Many species of marine opisthobranch molluscs similarly not only tolerate chemical defenses of their prey but are able to sequester them for their own use (Cimino \& Ghiselin 2009). However, we are not aware of reports of this occurring in any taxon of marine grazers other than opisthobranchs. The metabolic mechanisms responsible for sequestration are less studied than for tolerance, but include selective transport and storage of the defensive metabolites (Després et al. 2007).

As with amphipods from lower latitudes, Antarctic amphipods appear to benefit from associating with their chemically defended macroalga hosts because the algae provide a refuge from omnivorous fish predators. Along the western Antarctic Peninsula, densities of amphipods during daylight hours can be orders of magnitude higher on chemically defended macrophytes, particularly those with branching morphology, than on palatable macroalgae (Huang et al. 2007). Amphipod densities on Desmarestia menziesii, a chemically defended macrophyte supporting the greatest daytime amphipod densities, significantly decrease at night (Aumack et al. 2011a) when visual predators such are fish are less of a threat, while amphipod densities on blade-forming, chemically defended macrophytes and on palatable macrophytes increase. Zamzow et al. (2010) demonstrated that amphipods associated with $D$. menziesii were less susceptible to predation from the dominant, omnivorous fish than were amphipods associated with a non-defended macrophyte.

Although these Antarctic amphipods do not appear to consume most host macroalgae, they consume large quantities of epiphytic diatoms (Aumack 2010, Aumack et al. 2011b) which almost certainly benefits their hosts. Many studies throughout the world have shown that amphipods and other mesograzers can benefit their host macrophytes in this manner by limiting the growth of epiphytic microalgae and/or filamentous algae, which can compete with the macrophytes for light and nutrients (e.g. Brawley \& Adey 1981, Shacklock \& Doyle 1983, D'Antonio 1985, Brawley \& Fei 1987, Duffy 1990, Jernakoff et al. 1996). Although less studied, mesograzers can also influence filamentous algae growing endophyticly. Parker \& Chapman (1994) reported that when mesograzers were excluded from tide pools dominated by the brown alga Fucus distichus, fatal, pathogenic effects of otherwise unapparent filamentous algal endophytes drastically reduced the macroalgal canopy.

Free-living filamentous algae, epiphytic or otherwise, are very uncommon in subtidal communities along the western Antarctic Peninsula (Peters 2003) even though they are commonly present in adjoining intertidal areas (e.g. Delépine et al. 1966, Hedgpeth 1969, Chung et al. 1994, Kim 2001). However, filamentous algal endophytes growing within the larger, chemically defended macroalgae are unusually common (Peters 2003, Amsler et al. 2009b). Peters (2003) hypothesized that the high densities of macroalgalassociated amphipods in these Antarctic communities were preventing the growth of free-living filaments while selecting for an endophytic growth form, and this has been supported by experimental field, laboratory, and mesocosm studies (Amsler et al. 
2009b, 2012, Aumack et al. 2011b). Consequently, the dense assemblage of chemically defended Antarctic macroalgae benefits from the dense assemblage of amphipods associated with it because the amphipods limit the growth of both unicellular and filamentous epibionts on the macroalgae.

Since both the chemically defended macroalgae and the amphipods benefit from their association, this is a mutualistic relationship across the macroalgal and amphipod assemblages. As a consequence of the macroalgae dominating Antarctic Peninsular communities in terms of biomass and structure, and amphipods clearly being the most abundant and widespread invertebrates in these communities, this mutualistic relationship is likely to have widespread impacts on the community dynamics and/or structure of near shore communities along the western Antarctic Peninsula.

As mentioned, temperate and tropical mesograzers that specifically associate with chemically defended macroalgae are sometimes able to consume their hosts (Hay 1992, 1996). If macroalgal-associated amphipods along the western Antarctic Peninsula are also consuming significant quantities their hosts relative to the benefits they provide from eating epibionts, considering their association as a community level mutualism would not be appropriate. With one exception, none of our studies of trophic relationships in this community have given any indication that the amphipods are consuming the dominant, chemically defended macroalgae. The exception is for the amphipod Paradexamine fissicauda, which has previously been suggested to be broadly omnivorous (Momo et al. 1998). In a survey of the amphipod fauna associated with 8 common macroalgae in our study area, $P$. fissicauda was 2 to 3 orders of magnitude more abundant on the chemically defended red alga, Plocamium cartilagineum, than on any of the other 7 species (Huang et al. 2007). In a study including both amphipod gut content analyses and stable isotope composition, Aumack (2010) found a majority of the gut contents from Paradexamine fissicauda were macroalgal thallus or filaments. The stable isotope composition of $P$. fissicauda was the only one of 8 common amphipod species examined that closely matched Plocamium cartilagineum or other chemically defended red algae. No other possible dietary components sampled including diatoms or filamentous algal endophytes, either alone or in combination, would result in its isotopic signature-strongly suggesting that Paradexamine fissicauda is unlike other common amphipods in the community in being able to consume chemically defended red algae.
The first goal of the present study was to test the hypothesis that the amphipod Paradexamine fissicauda is unique among common amphipods in the community in being able to consume chemically defended macroalgae, particularly Plocamium cartilagineum. After discovering that this is indeed the case, we sought to determine if Paradexamine fissicauda might derive benefits in addition to having a defended algae as a food source, specifically by testing the hypothesis that it is able to sequester defensive algal metabolites for its own use.

\section{MATERIALS AND METHODS}

\section{Sample collection}

Subtidal macroalgae and associated amphipods were collected within $3.5 \mathrm{~km}$ of Palmer Station on Anvers Island, Antarctica ( $64^{\circ} 46.5^{\prime} \mathrm{S}, 64^{\circ} 03.3^{\prime} \mathrm{W}$; see Amsler et al. 2009b for map). All samples were collected by hand during SCUBA dives at 5 to $30 \mathrm{~m}$ depth during March through April 2010, February through May 2011, and March 2012. Following collection, the samples were kept submerged in buckets of seawater and transported to flow-through ambient seawater aquaria at Palmer Station. Fish were collected using baited traps submerged off the station dock. Macroalgae for use in secondary metabolite analyses were frozen at $-80^{\circ} \mathrm{C}$.

Macroalgae used in bioassays were held in flowthrough aquaria under ambient room lighting for a maximum of several days before use in experiments. Amphipods were collected on their host macroalgae following the techniques of Huang et al. (2007). The amphipods were sorted by species and maintained in 41 plastic bottles with screened windows to allow seawater exchange while floated in aquaria with flow-through, filtered ambient seawater. Each bottle had several pieces of algae on which the amphipods could graze or perch. Fish were held in a large, compartmented aquaria with flow-through seawater for approximately $1 \mathrm{wk}$ prior to the experiment. Each fish was fed 3 times daily with fresh limpet tissue delivered using long forceps.

\section{Feeding bioassays}

Several different feeding bioassays were conducted with amphipods, fish, and macroalgae over the course of $3 \mathrm{yr}$. To determine the palatability of the red alga Plocamium cartilagineum to the most common 
amphipods in the community, fresh thallus from the alga was bioassayed with 6 species of amphipods (Gondogeneia antarctica, Oradarea bidentata, Paradexamine fissicauda, Paraphimedia integricauda, Prostebbingia gracilis, and Schraderia gracilis) in 2010. In order to determine the range of chemically defended macroalgae that Paradexamine fissicauda is able to consume and their relative palatability, a set of no-choice experiments performed in late March and early April 2010, and repeated twice in 2011 (once in late March and early April, once in early to mid-May) examined the palatability of 6 red algal species (Cystoclonium obtusangulum, Delisea pulchra, Palmaria decipiens, Pantoneura plocamioides, Picconiella plumosa, and Plocamium cartilagineum) and 2 brown macroalgal species (Desmarestia anceps and Desmarestia menziesii) to the amphipod Paradexamine fissicauda. The second 2011 experiment did not include Delisea pulchra, Desmarestia anceps, and D. menziesii. Additionally, in March and May 2011 and in March 2012, 4-way choice experiments were conducted with Paradexamine fissicauda to examine preferential feeding on the red algae $C$. obtusangulum, Pantoneura plocamioides, Picconiella plumosa, and Plocamium cartilagineum.

Most bioassays were conducted with amphipods within a week of collection. However, 2 populations of Paradexamine fissicauda were maintained in the laboratory for 2 months in 2011, one on a diet of Plocamium cartilagineum and the other on a diet of Palmaria decipiens. Some of these amphipods were used in a fish feeding bioassay with the sympatric predator Notothenia coriiceps to determine if consuming the chemically defended algae affected the amphipod's palatability to the fish. The remainder of the amphipods were maintained for an additional week on a diet of Palmaria decipiens only. Paradexamine fissicauda feeds and clears its gut relatively rapidly and this time interval would have allowed the amphipods previously fed Plocamium cartilagineum to clear their guts multiple times. These amphipods were frozen at $-80^{\circ} \mathrm{C}$ and used for the secondary metabolite analyses detailed below in order to determine if the amphipods were sequestering defensive algal metabolites.

No-choice feeding rate bioassays generally followed methods described by Amsler et al. (2009b). Single amphipods were placed in each of twenty $60 \mathrm{ml}$ plastic bottles filled with filtered seawater. A small portion $(<5 \mathrm{mg})$ of an individual algal thallus was placed in each of the 20 bottles with amphipods. A similar portion from each alga was placed in a paired bottle without an amphipod to serve as autogenic control. No individual alga was used as the source of more than one experimental and autogenic control sample pair. The algae and amphipods were maintained at ambient temperatures by floating them in flow-through aquaria until a visible biomass had been consumed, or for a maximum of $4 \mathrm{~d}$. The seawater in all bottles was changed daily. Thallus biomass was determined at the beginning and end of the experiment by blotting the algal thallus dry and weighing it to the nearest $0.01 \mathrm{mg}$ on a Mettler Toledo XP 26 Deltarange microbalance. The amount of thallus consumed was calculated by subtracting the final mass from the initial mass after correcting by the ratio of initial:final mass in the paired autogenic control bottle. Amphipod feeding rates were expressed on a per individual per hour basis.

The 4-way choice experiments followed the nochoice methods with a few exceptions. A single Paradexamine fissicauda was placed in each of twenty $250 \mathrm{ml}$ plastic bottles with a small portion $(<5 \mathrm{mg})$ of each of the 4 red algae. A similar bottle lacking an amphipod served as the autogenic control. The bottles were maintained in a cold room at $1^{\circ} \mathrm{C}$ with a daily water change.

Only individual Notothenia coriiceps that readily fed from forceps were used in the fish feeding bioassay. Sixteen individuals were fed 3 times during $24 \mathrm{~h}$ a randomly assigned sequence of Bovallia gigantea (a predatory amphipod of equivalent size and with a spiny morphology similar to Paradexamine fissicauda), $P$. fissicauda maintained on a long term diet of Plocamium cartilagineum, or Paradexamine fissicauda maintained on a long term diet of Palmaria decipiens. The amphipods were released from forceps in front of the fishes' mouths. The fish, which had been accustomed to feeding in this manner, then took the amphipods into their mouths before determining to eat or reject them. In each trial, the amphipod was presented in the forceps with its dorsal side towards the fish. The amphipods were alive, but in order to control for any potential differences in escape behaviors between $B$. gigantea and Paradexamine fissicauda each animal was briefly immobilized immediately before being presented to the fish. This was done by quickly, partially drying the amphipod followed by very light (non-crushing) pressure on its head using the forceps. This was observed to immobilize the amphipods long enough for the fish to have an opportunity to either accept or reject them as food. After each trial the fish was offered (and consumed) fresh limpet tissue to check for satiation. 


\section{Statistical analyses}

Statistical analyses on amphipod feeding rates were performed using SPSS software (SPSS). Multiple comparisons utilized Mann-Whitney tests. Pairwise post hoc comparisons were made with KruskalWallis tests corrected for Type I error with the sequential Dunn-Sidak method (Sokal \& Rohlf 1995). Because of the larger number of pair-wise comparisons of Paradexamine fissicauda feeding rates on different macroalgal species in the 2010 and MarchApril 2011 no-choice experiments, for those 2 experiments alpha was set at 0.07 in the Dunn-Sidak method. In all other statistical analyses, alpha was set at 0.05 . Amphipod feeding rates were also individually compared to zero consumption with one-sample $t$-tests. Statistical analysis of fish acceptance vs. rejection of amphipods in feeding bioassays were performed with pair-wise, 2-tailed McNemar's test for correlated proportions using VassarStats (vassarstats.net) corrected for Type I error with the sequential Dunn-Sidak method.

\section{Secondary metabolite analyses}

Analysis of secondary metabolites from organisms used in this study was conducted by GC-MS. Algal thalli or amphipods were submerged in a solution of dichloromethane/methanol (3:1) for $24 \mathrm{~h}$, then decanted to produce a lipophilic extract. Injections of $1 \mu \mathrm{l}$ of a $1.0 \mathrm{mg} \mathrm{ml}^{-1}$ solution of algae or amphipod extract were introduced into the preheated splitless inlet at $250^{\circ} \mathrm{C}$ of an Agilent 7980A GC fitted with an HP-5ms column ( $30 \mathrm{~m} \times 0.25 \mathrm{~mm}$ i.d.) incubated at an initial oven temperature of $100^{\circ} \mathrm{C}$ for $2 \mathrm{~min}$, and heated to a final temperature of $250^{\circ} \mathrm{C}$ at a rate of $5^{\circ} \mathrm{C}$ $\mathrm{min}^{-1}$. A final temperature of $300^{\circ} \mathrm{C}$ was reached at a rate of $20^{\circ} \mathrm{C} \mathrm{min}^{-1}$, then this temperature held for a further 2 min. Helium was used as a carrier gas at a constant flow rate of $1 \mathrm{ml} \mathrm{min}{ }^{-1}$. Molecular ions were detected on an Agilent 7200 QTOF equipped with an electron ionization (EI) or chemical ionization (CI) source, using $2 \mathrm{ml} \mathrm{min}^{-1}$ methane as a ionization gas. Agilent MassHunter Qualitative Analysis software v. 4.0 was used for data processing.

\section{RESULTS}

Amphipod feeding rates on Plocamium cartilagineum differed significantly with species $\left(U_{5}=\right.$ $20.957, \mathrm{p}=0.001)$. Of the 6 amphipod species, only

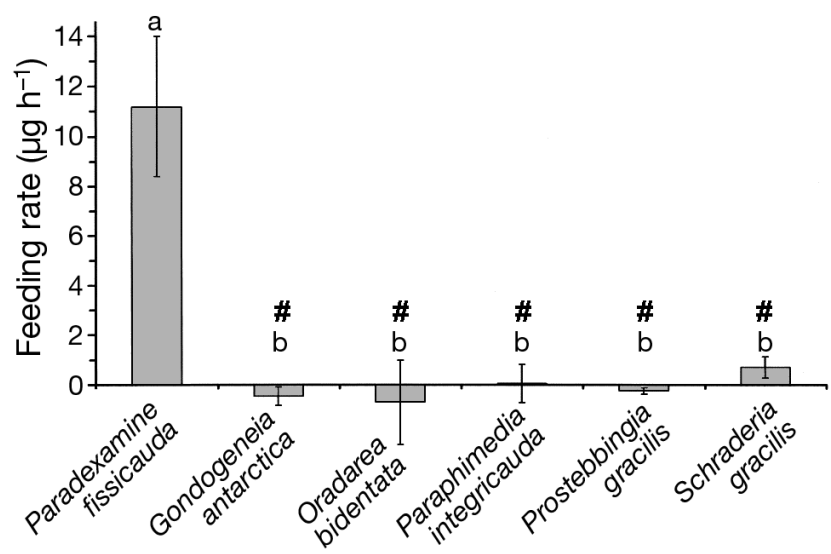

Fig. 1. Feeding rates (means $\pm \mathrm{SE}$ ) of individuals from various Antarctic amphipod species on thallus fragments of the red alga Plocamium cartilagineum. Letters indicate results of pair-wise comparisons of feeding rates on algal fragments. Bars with the same letters are not significantly different $(p>0.05)$. \# indicates that the data did not significantly differ from zero in a 1 -way $t$-test $(p>0.05)$

Paradexamine fissicauda consumed the red alga at appreciable rates (Fig. 1) and was the only amphipod species to consume Plocamium cartilagineum at a rate significantly different from zero consumption (1-sample $t$-tests, $\mathrm{p}<0.05$ ).

In no-choice feeding assays, feeding rates of freshly-collected Paradexamine fissicauda differed significantly with macroalgal species in all 3 experiments from both years. The 2010 results differed noticeably from both 2011 experiments in terms of relative consumption rates on some individual species, particularly Pantoneura plocamioides and Cystoclonium obtusangulum (Fig. 2, Table S1 in the supplement at www.int-res.com/articles/suppl/m490 p079_supp.pdf). However, the 2011 experiments also differed with respect to the relative difference between feeding rates on Palmaria decipiens compared to Plocamium cartilagineum and Picconiella plumosa (Fig. 2) and the absolute feeding rates on Plocamium cartilagineum and Picconiella plumosa (Table S1 in the supplement). Although the absolute feeding rates on Pantoneura plocamioides and $C$. obtusangulum were very low in both 2011 experiments, they were much less variable in the May experiment and were both significantly different from zero consumption then $(p=0.009$ and $<0.0005$, respectively), but not in the March-April experiment $(\mathrm{p}=0.400$ and 0.176 , respectively). Feeding rates were not significantly different from zero in Delisea pulchra, Desmarestia menziesii, and Desmarestia anceps in either the March-April 2010 or March-April 2011 experiments; and because of 

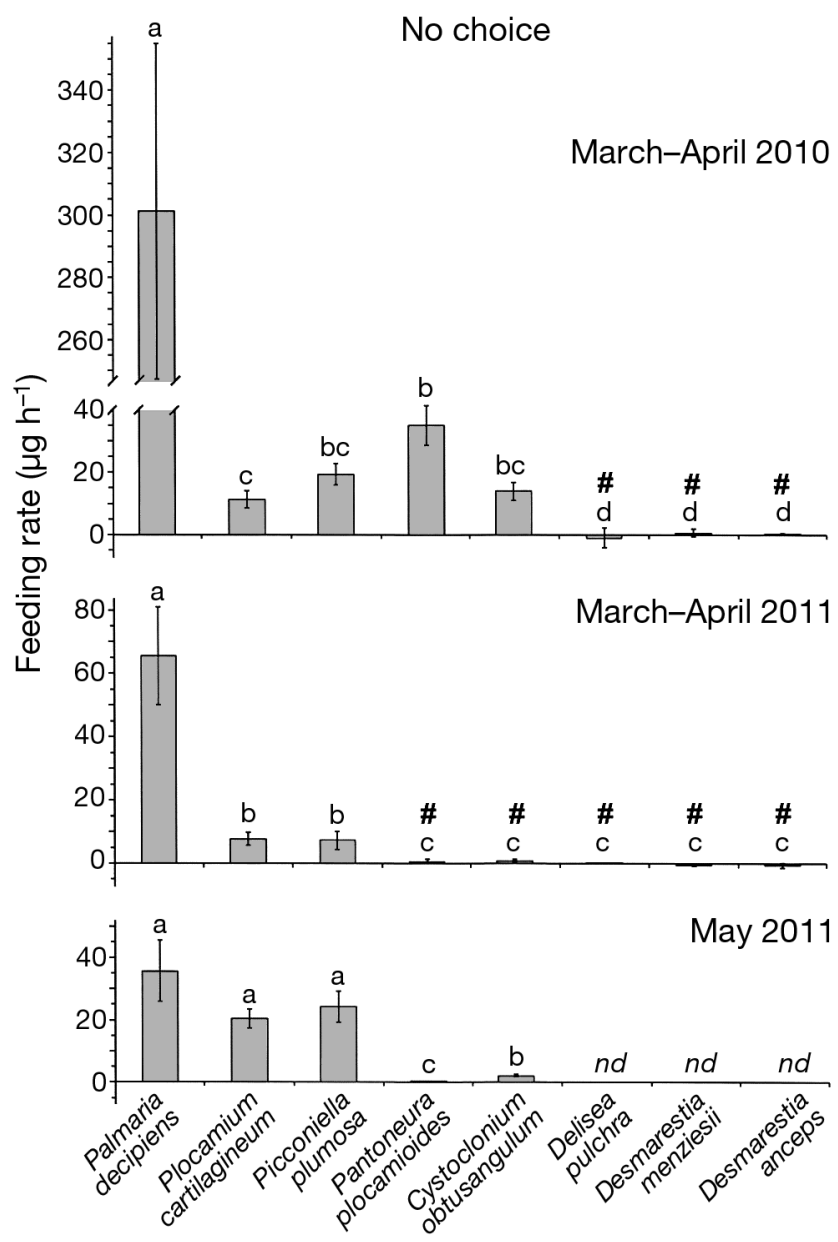

Fig. 2. Paradexamine fissicauda. No-choice feeding rates (means $\pm \mathrm{SE}$ ) of individual $P$. fissicauda on thallus fragments of various Antarctic red and brown macroalgal species from 3 separate experiments. Multiple comparison tests indicated significant differences between rates in all 3 experiments (March-April 2010: $U_{7}=93.869$; March-April 2011: $U_{7}=$ 69.582; May 2011: $U_{4}=46.186$; $p<0.0005$ in all 3 results). Roman letters above bars indicate results of pair-wise comparisons of feeding rates on algal fragments within each experiment. Bars with the same roman letters are not significantly different $(p>0.07$ in both March-April experiments, p > 0.05 in May 2011 experiment). \# indicates that the data did not significantly differ from zero in a 1-way $t$-test $(\mathrm{p}>$ $0.05)$; nd indicates that these 3 species were not included in the May 2011 experiment

that, combined with time constraints, they were not included in the May 2011 experiment.

The 4 red algal species that were consumed by Paradexamine fissicauda in the 2010 experimentbut were known from previous studies to be unpalatable to other amphipod species because of chemical defenses (Aumack et al. 2010) and often also to fish and sea stars (Amsler et al. 2005) - were chosen for use in 4-way choice experiments in 2011 and 2012.

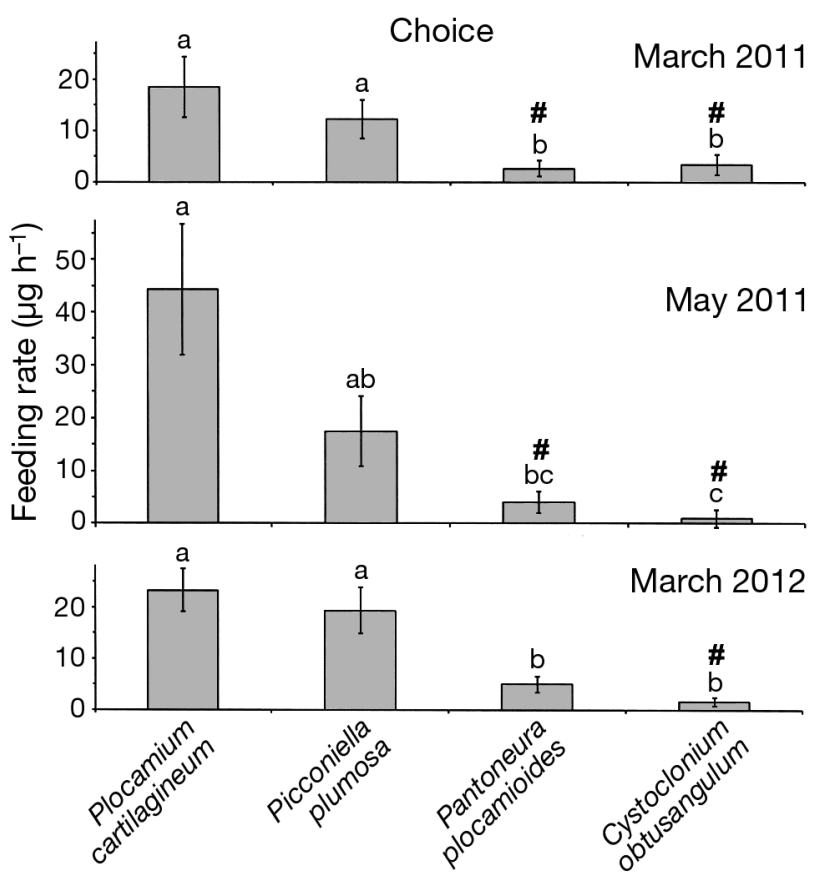

Fig. 3. Paradexamine fissicauda. Feeding rates (means \pm SE) of individual $P$. fissicauda on thallus fragments of 4 Antarctic red macroalgal species from 3 separate choice experiments. Multiple comparison tests indicated significant differences between rates in all 3 experiments (March 2011: $U_{3}=25.748$; May 2011: $U_{3}=25.545 ;$ March 2012: $U_{3}=27.570 ; \mathrm{p}<0.0005$ in all 3 results). Letters above bars indicate results of pairwise comparisons of feeding rates on algal fragments within each experiment. Bars with the same letters are not significantly different $(\mathrm{p}>0.05)$. \# indicates that the data did not

significantly differ from zero in a 1 -way $t$-test $(\mathrm{p}>0.05)$

Overall patterns were very similar between all 3 experiments with Plocamium cartilagineum and Picconiella plumosa being consumed at statistically indistinguishable rates (Fig. 3). Likewise, Pantoneura plocamioides and Cystoclonium obtusangulum were consumed at statistically indistinguishable rates that, with one exception, did not significantly differ from zero consumption in 1-sample $t$-tests (Fig. 3). With the exception of the May 2011 experiment when the feeding rate on Picconiella plumosa did not significantly differ from Pantoneura plocamioides, the rates on Plocamium cartilagineum and Picconiella plumosa were significantly greater than on the other 2 species (Fig. 3).

Acceptance of amphipods by fish in bioassays differed significantly between Plocamium cartilagineum-fed Paradexamine fissicauda and both of the other choices (Fig. 4). Only 2 of 16 P. fissicauda that had been maintained for 2 months on a diet of Plocamium cartilagineum were consumed, but that increased to 9 of 16 for Paradexamine fissicauda main- 


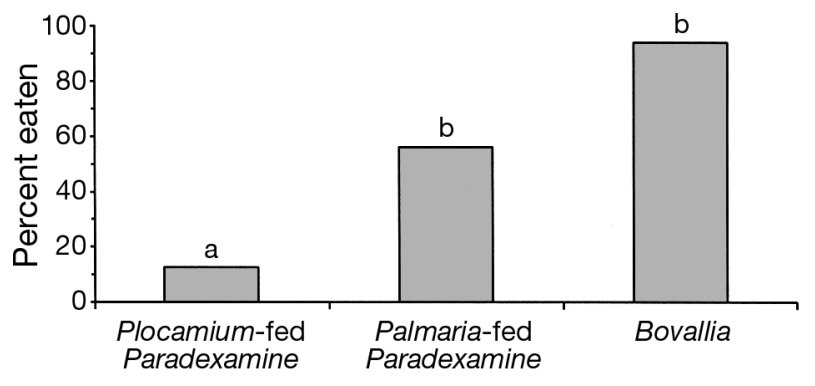

Fig. 4. Notothenia coriiceps. Percent of amphipods consumed by the fish $N$. coriiceps. Letters above bars indicate results of pair-wise comparisons of the numbers consumed. Bars with the same letters are not significantly different $(p>0.05)$

tained on Palmaria decipiens and to all but 1 of 16 Bovallia gigantea that had recently been collected from the field. The difference in fish acceptance of Palmaria decipiens-fed Paradexamine fissicauda compared to fish acceptance of B. gigantea was only marginally significant $(\mathrm{p}=0.07)$.

Chemical analysis of lipophilic extracts of Plocamium cartilagineum collected from the vicinity of Palmer Station demonstrated a mixture of halogenated monoterpenes, while Palmaria decipiens was devoid of them (Fig. S1 in the supplement). Lipophilic extracts of Paradexamine fissicauda maintained on Plocamium cartilagineum showed chromatographic features (peaks) at retention times that correlated with P. cartilagineum halogenated monoterpenes (Fig. S2). P. cartilagineum chemistry in Paradexamine fissicauda extracts was confirmed by comparison of the mass spectral fragmentation pattern of the 15.5 min feature found in both chromatograms (Figs. S3 \& S4). The chromatogram of $P$. fissicauda maintained on a diet of Palmaria decipiens lacked features associated halogenated compounds (Fig. S5).

\section{DISCUSSION}

These results validate our stable isotope composition-based hypothesis that Paradexamine fissicauda consumes the chemically defended macroalga, Plocamium cartilagineum, on which it is most commonly found in nature (Huang et al. 2007). Moreover, as also expected from previous chemical ecology studies in Antarctica (Amsler et al. 2005, Aumack et al. 2010) and from stable isotope signatures (Aumack 2010), it was unique among 6 relatively common amphipod species examined in being able to consume $P$. cartilagineum, even though all of these amphipod species have been reported from $P$. cartilagineum in the study area (Huang et al. 2007).

The observation that Paradexamine fissicauda maintained on a diet of Plocamium cartilagineum contained halogenated metabolites derived from the algae and were almost always rejected by the omnivorous fish Notothenia coriiceps indicates that Paradexamine fissicauda is able to sequester at least some of the potent chemical defenses of Plocamium cartilagineum for its own use as a defense. The $P$. cartilagineum-fed Paradexamine fissicauda were rejected significantly more often than $P$. fissicauda which had been maintained on the undefended alga Palmaria decipiens (and did not contain halogenated metabolites) and also significantly more often than the similar amphipod Bovallia gigantea. We have not yet identified the specific metabolites involved, but lipophilic extracts of Plocamium cartilagineum are strongly deterrent to feeding of $N$. coriiceps in artificial food bioassays (Amsler et al. 2005) and P. cartilagineum secondary metabolites in the amphipods would presumably also deter the fish if present in sufficient concentrations. Rejection of the amphipods by the fish was rapid and the amphipods were not crushed, so it seems likely that the responsible compounds are present in the exoskeleton. This, however, remains to be determined.

The main predators of macroalgal-associated amphipods along the western Antarctic Peninsula are probably fish, particularly the large omnivore Notothenia coriiceps (cf. Zamzow et al. 2010, 2011). Some Paradexamine fissicauda were present in the gut contents of some $N$. coriiceps from 2 of 3 collection sites in our study area - but even at those 2 sites, with low relative frequencies of occurrence and with relative importance indices (an assessment of their importance to the fish) of zero (Zamzow et al. 2011). Hence, although $P$. fissicauda is sometimes consumed by fish in nature, this does not appear to be frequent, and its relative unpalatability presumably provides a competitive advantage to $P$. fissicauda compared to sympatric amphipod species which are palatable to fish.

The observation that Palmaria decipiens-fed Paradexamine fissicauda were rejected at a marginally greater rate than were Bovallia gigantea could indicate that some proportion of sequestered defenses had been maintained within $P$. fissicauda tissues during the 2 months they were not able to feed on Plocamium cartilagineum; although if so, either these metabolites are not halogenated or are retained at levels below detection limits in our chemical analyses. Alternately, it could indicate that a structural 
trait of Paradexamine fissicauda not present in $B$. gigantea also helps deter fish feeding. Compared to $P$. fissicauda, B. gigantea is somewhat larger and has larger but less dense spines.

Savitzky et al. (2012) have recently defined sequestration as 'the evolved retention within tissues of specific compounds, not normally retained in the ancestors of the taxon in question, which confers a selective advantage through one or more particular functions.' In marine systems, some opisthobranch molluscs are known to sequester macroalgal defenses (reviewed by Jormalainen \& Honkanen 2008, Cimino \& Ghiselin 2009, Hay 2009), but as noted previously we are aware of no examples of this in amphipods or other marine arthropods. Complete evidence for sequestration of defensive compounds by Paradexamine fissicauda will require identification of the specific dietary-derived defensive metabolites in their tissues or exoskeletons at concentrations which are shown to be deterrent to fish, but it appears that such sequestration of defenses is clearly occurring in and providing a selective advantage to $P$. fissicauda.

The use of chemical defenses in other aquatic arthropods is almost unknown. Luckenbach \& Orth (1990) provided circumstantial evidence that the small, parasitic crab Pinnotheres ostreum deters predators with some form of chemical secretion that is only produced or released by live crabs. Lipophilic extracts of (and intact, live) brooded juveniles of the Antarctic isopod Glyptonotus antarcticus are unpalatable to predatory sea stars (McClintock et al. 2003). In both cases there is neither evidence nor reason to expect that the defenses have a dietary origin. Dietary accumulation of microalgal-derived toxins is known in crabs and lobsters, primarily localized to the hepatopancreas and primarily as the result of consumption of filter-feeding bivalves that have bioaccumulated toxins from harmful microalgal species (Shumway 1995), but there is no evidence that the crustaceans derive any benefits from this. Some amphipods, while not sequestering defenses from other organisms into their own tissues, are known to deter predators by attaching themselves to chemically defended species. In Antarctica, the pelagic amphipod Hyperiella dilatata captures and holds onto the chemically defended pteropod Clione antarctica to deter fish predators (McClintock \& Janssen 1990). Some crustaceans are known to cover themselves with chemically defended algae for protection (Hay et al. 1990, Stachowicz \& Hay 1999). For example, the amphipod Pseudamphithoides incurvaria is a dietary specialist on chemically defended brown algae and constructs portable, envelope-like domiciles from one, Dictyota bartayresii, which protect it from fish predation (Hay et al. 1990).

Plocamium cartilagineum is one of the most common understory red macroalgae in almost all published qualitative, semi-quantitative, or quantitative reports from along the western Antarctic Peninsula (Neushul 1965, DeLaca \& Lipps 1976, Zielinski 1981, 1990, Westermeier et al. 1992, Chung et al. 1994, Klöser et al. 1994, 1996, Amsler et al. 1995, Brouwer et al. 1995, Quartino et al. 2001, 2005, Quartino \& Boraso de Zaixso 2008, see Wiencke et al. in press for distribution map). Based on our personal observations during many hundreds of dives at dozens of sites in our study area, it is probably the most abundant chemically defended red alga with the highly branched morphology preferred by Antarctic amphipods (Huang et al. 2007). Consequently, it would seem that selection for tolerance to defensive compounds produced by $P$. cartilagineum would be particularly beneficial to Paradexamine fissicauda. The amphipods should not only benefit from associational refuge from predators as discussed previously, but tolerance of this host's defenses also benefits $P$. fissicauda by providing it with an additional and widespread food source (cf. Sotka \& Whalen 2008).

Plocamium cartilagineum from Antarctica produces a variety of halogenated monoterpenes (Stierle \& Sims 1979, Stierle et al. 1979, Cueto et al. 1991, Ankisetty et al. 2004) including at least 2 (anverene and epi-plocamene D) which deter feeding by the amphipod Gondogeneia antarctica (Ankisetty et al. 2004). Its lipophilic extract was one of only 3 crude extracts from 27 macroalgal species (along with lipophilic extracts of Desmarestia menziesii and Delisea pulchra) which suppressed $100 \%$ of feeding by $G$. antarctica in artificial food bioassays (Amsler et al. 2005). Because of the diversity of possible chemical defenses, the specific enzymes needed for tolerance are commonly specific to particular defensive compounds, and herbivores that specialize on particular chemically defended hosts often have limited ability to tolerate defensive compounds from other organisms (e.g. Sorensen et al. 2005).

The other 2 macroalgal species also consumed by Paradexamine fissicauda in all bioassays were Palmaria decipiens and Picconiella plumosa. P. plumosa has been shown to be chemically defended from consumption by the amphipods Gondogeneia antarctica and Prostebbingia gracilis (Amsler et al. 2005, Aumack et al. 2010). It is comparable to Plocamium cartilagineum in terms of protein content and other determinants of nutritional value (Peters et al. 2005). 
Its carbon isotope ratio $(-34.5 \%$, C. F. Aumack unpubl. data) is close to that of $P$. cartilagineum and Paradexamine fissicauda and we observe $P$. fissicauda associating with Picconiella plumosa more frequently than other, more abundant, rhodophytes in nature (Aumack 2010). We do not know anything about its defensive metabolites, but they may be similar enough to those of Plocamium cartilagineum to be detoxified by the same pathway. Picconiella plumosa is widely distributed along the western Antarctic Peninsula, particularly at depths exceeding $20 \mathrm{~m}$ (Wiencke \& Clayton 2002, Hommersand et al. 2009), and as such represents a second chemically defended red alga that Paradexamine fissicauda is able to exploit as a refuge and food source.

Palmaria decipiens, the third red alga regularly consumed by Paradexamine fissicauda in our assays, is one of the most generally palatable macroalgal species in the community (Amsler et al. 2005, 2009b, Aumack et al. 2010) and although not all amphipod species consume it as fresh thallus (Aumack et al. 2010, Bucolo et al. 2011), this is not attributable to chemical defenses (Aumack et al. 2010). In nature, Palmaria decipiens supports a far less abundant amphipod fauna than other, chemically defended species (probably because they are more likely to be consumed by omnivorous fish on P. decipiens; Zamzow et al. 2010) and Paradexamine fissicauda was not found on it during 2 surveys (Huang et al. 2007, Aumack et al. 2011a). Moreover, the stable carbon isotope ratio in Palmaria decipiens is very different from that of Paradexamine fissicauda (Aumack 2010) so it is unlikely that Palmaria decipiens is an important food source for Paradexamine fissicauda in nature. There is no obvious explanation for the dramatically higher consumption of Palmaria decipiens in 2010 compared to the 2 no-choice experiments in 2011 (Fig. 2). P. decipiens is a pseudo-perennial (Wiencke \& Clayton 2002) that dies back to a crustose holdfast in winter. By May, many (if not most) of the blades in our study area have completely senesced (authors' pers. obs.) so it is possible that the reason the May 2011 feeding rate on the P. decipiens material we were able to collect was not different from rates on Plocamium cartilagineum or Picconiella plumosa was due to decreased nutritional quality of the remaining Palmaria decipiens. It is also possible that $P$. decipiens began to senesce earlier in 2011 than 2010, resulting in a lower nutritional quality and, hence, the lower feeding rate on it in MarchApril 2011 compared to 2010. However, we have not examined the influence of nutritional quality on feeding in any amphipod species in this community.
Feeding rates on Pantoneura plocamioides and Cystoclonium obtusangulum in no-choice assays were comparable to or higher than on Plocamium cartilagineum and Picconiella plumosa in the 2010 assays, but were much lower and often not significantly different from zero in the 2011 and 2012 nochoice and choice bioassays. Aumack et al. (2010) reported that in collections made in 2007 and 2008, both Pantoneura plocamioides and C. obtusangulum were unpalatable as fresh thallus and as chemical extracts to the amphipods Gondogeneia antarctica and Prostebbingia gracilis. However, Amsler et al. (2005) found no significance deterrence to feeding by G. antarctica in Pantoneura plocamioides extracts prepared from material collected in March-April 2000 (C. obtusangulum was not included in that study). It appears that there may be significant interannual (or, perhaps, collection site) variation in the defensive chemistry of $P$. plocamioides and probably C. obtusangulum. Because of the observation of differences across studies in deterrence to G. antarctica in addition to that seen here for Paradexamine fissicauda, with respect at least to Pantoneura plocamioides it is likely that the differences observed across years are not due to variation in specific defenses that Paradexamine fissicauda is able to tolerate but that other amphipods are not.

Three species, Desmarestia menziesii, Desmarestia anceps, and Delisea pulchra, were not consumed at rates significantly different from zero in either the March-April 2010 or 2011 no-choice assays. All 3 are unpalatable to fish and sea stars as fresh thallus and in crude extracts (Amsler et al. 2005). Both Desmarestia spp. are unpalatable to the amphipod Gondogeneia antarctica as fresh thallus (Amsler et al. 2009b) and crude extract (Amsler et al. 2005). Delisea pulchra extracts are strongly deterrent to G. antarctica (Amsler et al. 2005) but we have not performed fresh thallus feeding assays on it using any amphipod other than Paradexamine fissicauda.

In summary, Paradexamine fissicauda benefits from its ability to both live on and consume some of the chemically defended macroalgae in its community, as has sometimes been observed in temperate and tropical amphipod species (Hay 1992, 1996). It appears to sequester host defenses for its own use, which is a novel observation in marine arthropods. Other prominent macroalgal-associated amphipods in this community are thought to be in a communitywide mutualistic relationship with the dominant, chemically defended macroalgae. They benefit from an associational defense from fish predation (Zamzow et al. 2010) while the macroalgae benefit from a 
reduction of epiphytic diatoms and filamentous algae as well as emergent filaments of algal endophytes (Amsler et al. 2009b, Aumack et al. 2011b). P. fissicauda would still benefit from the associational defense and may also consume some epiphytic diatoms and filamentous macroalgae (although its stable carbon isotope signature suggests that any such consumption is likely minimal; Aumack 2010). However, with respect to community-wide mutualism, this species appears to 'cheat' the system by being able to exploit its chemically defended hosts for food as well as for shelter.

Acknowledgements. We are grateful to the other members of our 2010, 2011, and 2012 Antarctic field teams for tireless assistance; to C. Barhate for preliminary chemical analysis of the algae and amphipods, to R. Angus for statistical advice, and to P. Steinberg and several anonymous reviewers for constructive comments on early versions of the manuscript. This work would not have been possible without outstanding logistical support in Antarctica from the employees and sub-contractors of Raytheon Polar Services Company. Supported by National Science Foundation awards ANT0838773 and ANT-1041022 (C.D.A, J.B.M) and ANT0838776 (B.J.B) from the Antarctic Organisms and Ecosystems program, and by an Endowed Professorship in Polar and Marine Biology to J.B.M provided by the University of Alabama at Birmingham.

\section{LITERATURE CITED}

Amsler CD, Rowley RJ, Laur DR, Quetin LB, Ross RM (1995) Vertical distribution of Antarctic Peninsular macroalgae: cover, biomass, and species composition. Phycologia 34: 424-430

Amsler CD, Iken K, McClintock JB, Amsler MO and others (2005) Comprehensive evaluation of the palatability and chemical defenses of subtidal macroalgae from the Antarctic Peninsula. Mar Ecol Prog Ser 294:141-159

Amsler CD, McClintock JB, Baker BJ (2008) Macroalgal chemical defenses in polar marine communities. In: Amsler CD (ed) Algal chemical ecology. Springer-Verlag, Berlin, p 91-103

Amsler CD, Iken K, McClintock JB, Baker BJ (2009a) Defenses of polar macroalgae against herbivores and biofoulers. Bot Mar 52:535-545

Amsler CD, Amsler MO, McClintock JB, Baker BJ (2009b) Filamentous algal endophytes in macrophytic Antarctic algae: prevalence in hosts and palatability to mesoherbivores. Phycologia 48:324-334

> Amsler CD, McClintock JB, Baker BJ (2012) Amphipods exclude filamentous algae from the Western Antarctic Peninsula benthos: experimental evidence. Polar Biol 35: 171-177

Ankisetty S, Nandiraju S, Win H, Park YC and others (2004) Chemical investigation of predator-deterred macroalgae from the Antarctic Peninsula. J Nat Prod 67:1295-1302

Aumack CF (2010) Chemically mediated macroalgalmesograzer interactions along the Western Antarctic Peninsula. PhD dissertation, University of Alabama at
Birmingham

Aumack CF, Amsler CD, McClintock JB, Baker BJ (2010) Chemically mediated resistance to mesoherbivory in finely branched macroalgae along the western Antarctic Peninsula. Eur J Phycol 45:19-26

Aumack CF, Amsler CD, McClintock JB, Baker BJ (2011a) Changes in amphipod densities among macroalgal habitats in day versus night collections along the Western Antarctic Peninsula. Mar Biol 158:1879-1885

> Aumack CF, Amsler CD, McClintock JB, Baker BJ (2011b) Impacts of mesograzers on epiphyte and endophyte growth associated with chemically defended macroalgae from the western Antarctic Peninsula: a mesocosm experiment. J Phycol 47:36-41

Blum MS (1983) Detoxification, deactivation, and utilization of plant compounds by insects. In: Hedin PA (ed) Plant resistance to insects, Vol 208. American Chemical Society, Washington, p 265-275

Brawley SH (1992) Mesoherbivores. In: John DM, Hawkins SJ, Price JH (eds) Plant-animal interactions in the marine benthos. Clarendon Press, Oxford, p 235-263

> Brawley SH, Adey WH (1981) The effect of micrograzers on algal community structure in a coral reef microcosm. Mar Biol 61:167-177

> Brawley SH, Fei XG (1987) Studies of mesoherbivory in aquaria and in an unbarricaded mariculture farm on the Chinese coast. J Phycol 23:614-623

> Brouwer PEM, Geilen EFM, Gremmen NJM, van Lent F (1995) Biomass, cover and zonation pattern of sublittoral macroalgae at Signy Island, South Orkeny Islands, Antarctica. Bot Mar 38:259-270

> Bucolo P, Amsler CD, McClintock JB, Baker BJ (2011) Palatability of the Antarctic rhodophyte Palmaria decipiens (Reinsch) RW Ricker and its endo/epiphyte Elachista antarctica Skottsberg to sympatric amphipods. J Exp Mar Biol Ecol 396:202-206

Buschmann AH, Vergara PA (1993) Effect of rocky intertidal amphipods on algal recruitment: a field study. J Phycol 29:154-159

Chung H, Oh YS, Lee IK, Kim DY (1994) Macroalgal vegetation of Maxwell Bay in King George Island, Antarctica. Korean J Phycol 9:47-58

Cimino G, Ghiselin MT (2009) Chemical defense and the evolution of opisthobranch gastropods. Proc Calif Acad Sci 60:175-422

Cueto M, Darias J, San Martin A, Rovirosa A, Seldes A (1991) Metabolitos secundarios de organismos marinos antárticos. In: Castellví J (ed) Actas del cuarto Simposio Español de Estudios Antárticos, Puerto de la Cruz, 20-25 de octubre de 1991. Comisión Interministerial de Ciencia y Technología, Madrid, p 95-101

D'Antonio C (1985) Epiphytes on the rocky intertidal red alga Rhodomela latrix (Turner) C. Agardh: negative effects on the host and food for herbivores? J Exp Mar Biol Ecol 86:197-218

DeLaca TE, Lipps JH (1976) Shallow water marine associations, Antarctic Peninsula. Antarct J US 11:12-20

Delépine R, Lamb IM, Zimmerman MH (1966) Preliminary report on the marine vegetation of the Antarctic Peninsula. Proc Int Seaweed Symp 5:107-116

> Després L, David JP, Gallet C (2007) The evolutionary ecology of insect resistance to plant chemicals. Trends Ecol Evol 22:298-307

Duffy JE (1990) Amphipods on seaweeds: partners or pests? Oecologia 83:267-276 
Duffy JE, Hay ME (1991) Amphipods are not all created equal: a reply to Bell. Ecology 72:354-358

Duffy JE, Hay ME (1994) Herbivore resistance to seaweed chemical defense: the roles of mobility and predation risk. Ecology 75:1304-1319

Duffy JE, Hay ME (2000) Strong impacts of grazing amphipods on the organization of a benthic community. Ecol Monogr 70:237-263

Hay ME (1992) The role of seaweed chemical defenses in the evolution of feeding specialization and in the mediation of complex interactions. In: Paul VJ (ed) Ecological roles for marine natural products. Comstock Press, Ithaca, NY, p 93-118

> Hay ME (1996) Marine chemical ecology: what's known and what's next? J Exp Mar Biol Ecol 200:103-134

Hay ME (2009) Marine chemical ecology: Chemical signals and cues structure marine populations, communities, and ecosystems. Annu Rev Mar Sci 1:193-212

Hay ME, Duffy JE, Fenical W (1990) Host-plant specialization decreases predation on a marine amphipod: an herbivore in plant's clothing. Ecology 71:733-743

> Heck KL Jr, Valentine JF (2006) Plant-herbivore interactions in seagrass meadows. J Exp Mar Biol Ecol 330:420-436

Hedgpeth JW (1969) Preliminary observations of life between tidemarks at Palmer Station, $64^{\circ} 45^{\prime} \mathrm{S}, 64^{\circ} 05^{\prime} \mathrm{W}$. Antarct J US 4:106-107

> Hillebrand H (2009) Meta-analysis of grazer control of periphyton biomass across aquatic ecosystems. J Phycol 45: 798-806

> Holmlund MB, Peterson CH, Hay ME (1990) Does algal morphology affect amphipod susceptibility to fish predation? J Exp Mar Biol Ecol 139:65-83

> Hommersand MH, Moe RL, Amsler CD, Fredericq S (2009) Notes on the systematics and biogeographical relationships of Antarctic and Sub-Antarctic Rhodophyta with descriptions of four new genera and five new species. Bot Mar 52:509-534

> Huang YM, Amsler MO, McClintock JB, Amsler CD, Baker BJ (2007) Patterns of gammarid amphipod abundance and species composition associated with dominant subtidal macroalgae along the western Antarctic Peninsula. Polar Biol 30:1417-1430

Jernakoff P, Brearley A, Nielsen J (1996) Factors affecting grazer-epiphyte interactions in temperate seagrass meadows. Oceanogr Mar Biol Annu Rev 34:109-162

Jormalainen V, Honkanen T (2008) Macroalgal chemical defenses and their roles in structuring temperate marine communities. In: Amsler CD (ed) Algal chemical ecology. Springer-Verlag, Berlin, p 57-89

Karban R, Agrawal AA (2002) Herbivore offense. Annu Rev Ecol Syst 33:641-664

Kim D (2001) Seasonality of marine algae and grazers of an Antarctic rocky intertidal, with emphasis on the role of the limpet Nacella concinna Strebel (Gastropoda: Patellidae). Ber Polarforsch Meeresforsch 397:1-120

> Klöser H, Mercuri G, Laturnus F, Quartino ML, Wiencke C (1994) On the competitive balance of macroalgae at Potter Cove (King George Island, South Shetlands). Polar Biol 14:11-16

> Klöser H, Quartino ML, Wiencke C (1996) Distribution of macroalgae and macroalgal communities in gradients of physical conditions in Potter Cove, King George Island, Antarctica. Hydrobiologia 333:1-17

> Luckenbach MW, Orth RJ (1990) A chemical defense in Crustacea? J Exp Mar Biol Ecol 137:79-87
McClintock JB, Janssen J (1990) Pteropod abduction as a chemical defense in a pelagic antarctic amphipod. Nature 346:462-464

McClintock JB, Mahon AR, Peters KJ, Amsler CD, Baker BJ (2003) Chemical defences in embryos and juveniles of two common Antarctic sea stars and an isopod. Antarct Sci 15:339-344

Momo F, Bogazzi E, Duttweiler F (1998) Amphipods of Potter Cove: community composition, biology and growth. Ber Polarforsch 299:144-149

Neushul M (1965) Diving observation of sub-tidal Antarctic marine vegetation. Bot Mar 8:234-243

Nishida R (2002) Sequestration of defensive substances from plants by Lepidoptera. Annu Rev Entomol 47:57-92

$>$ Opitz SEW, Muller C (2009) Plant chemistry and insect sequestration. Chemoecology 19:117-154

> Parker T, Chapman ARO (1994) Separating the grazing effects of periwinkles and amphipods on a seaweed community dominated by Fucus distichus. Ophelia 39:75-91

Peters AF (2003) Molecular identification, taxonomy and distribution of brown algal endophytes, with emphasis on species from Antarctica. Proc Int Seaweed Symp 17: 293-302

Peters KJ, Amsler CD, Amsler MO, McClintock JB, Dunbar RB, Baker BJ (2005) A comparative analysis of the nutritional and elemental composition of macroalgae from the western Antarctic Peninsula. Phycologia 44:453-463

> Poore AGB, Campbell AH, Steinberg PD (2009) Natural densities of mesograzers fail to limit growth of macroalgae or their epiphytes in a temperate algal bed. J Ecol 97:164-175

> Quartino ML, Boraso de Zaixso AL (2008) Summer macroalgal biomass in Potter Cove, South Shetland Islands, Antarctica: its production and flux to the ecosystem. Polar Biol 31:281-294

Quartino ML, Klöser H, Schloss IR, Wiencke C (2001) Biomass and associations of benthic marine macroalgae from the inner Potter Cove (King George Island, Antarctica) related to depth and substrate. Polar Biol 24: 349-355

- Quartino ML, Zaixso HE, Boraso de Zaixso AL (2005) Biological and environmental characterization of marine macroalgal assemblages in Potter Cove, South Shetland Islands, Antarctica. Bot Mar 48:187-197

Richardson MG (1971) The ecology and physiological aspects of Antarctic weed dwelling amphipods (Preliminary report, II). Brit Antarct Surv Rep N9/1971(-72)/H:1-16

Richardson MG (1977) The ecology (including physiological aspects) of selected Antarctic marine invertebrates associated with inshore macrophytes. PhD dissertation, University of Durham

Savitzky AH, Mori A, Hutchinson DA, Saporito RA, Burghardt GM, Lillywhite HB, Meinwald J (2012) Sequestered defensive toxins in tetrapod vertebrates: principles, patterns, and prospects for future studies. Chemoecology 22:141-158

Shacklock PF, Doyle RW (1983) Control of epiphytes in seaweed cultures using grazers. Aquaculture 31:141-150

Shumway SE (1995) Phycotoxin-related shellfish poisoning: bivalve molluscs are not the only vectors. Rev Fish Sci 3:1-31

Sokal RR, Rohlf FJ (1995) Biometry. WH Freeman, New York, NY

Sorensen JS, McLister JD, Dearing MD (2005) Novel plant secondary metabolites impact dietary specialists more 
than generalists (Neotoma spp.). Ecology 86:140-154

Sorensen JS, Skopec MM, Dearing MD (2006) Application of pharmacological approaches to plant-mammal interactions. J Chem Ecol 32:1229-1246

Sotka EE, Whalen KE (2008) Herbivore offense in the sea: the detoxification and transport of secondary metabolites. In: Amsler CD (ed) Algal chemical ecology. Springer-Verlag, Berlin, p 203-228

Sotka EE, Hay ME, Thomas JD (1999) Host-plant specialization by a non-herbivorous amphipod: advantages for the amphipod and costs for the seaweed. Oecologia 118: 471-482

Stachowicz JJ, Hay ME (1999) Reducing predation through chemically mediated camouflage: indirect effects of plant defenses on herbivores. Ecology 80:495-509

Stierle DB, Sims JJ (1979) Marine natural products - XV: Polyhalogenated cyclic monoterpenes from the red alga Plocamium cartilagineum of Antarctica. Tetrahedron 35: 1261-1265

Stierle DB, Wing RM, Sims JJ (1979) Marine natural products - XVI: Polyhalogenated acyclic monoterpenes from the red alga Plocamium of Antarctica. Tetrahedron 35: 2855-2859

Taylor RB, Steinberg PD (2005) Host use by Australasian seaweed mesograzers in relation to feeding preferences of larger grazers. Ecology 86:2955-2967

Westermeier R, Gómez I, Rivera PJ, Müller DG (1992) Macroalgas marinas antárticas: distribución, abundancia

Editorial responsibility: Peter Steinberg,

Sydney, New South Wales, Australia y necromasa en isla Rey Jorge, Shetland del Sur, Antártica. Ser Cient INACH 42:21-34

Wiencke C, Amsler CD (2012) Seaweeds and their communities in polar regions. In: Wiencke C, Bischof K (eds) Seaweed biology: novel insights into ecophysiology, ecology and utilization. Springer-Verlag, Berlin, p 265-294

Wiencke C, Clayton MN (2002) Antarctic seaweeds. ARG Gantner Verlag KG, Ruggell

Wiencke C, Amsler CD, Clayton MN (in press) Macroalgae. In: De Broyer C, Koubbi P (eds) Biogeographic atlas of the Southern Ocean. Scientific Committee on Antarctic Research

Zamzow JP, Amsler CD, McClintock JB, Baker BJ (2010) Habitat choice and predator avoidance by Antarctic amphipods: the roles of algal chemistry and morphology. Mar Ecol Prog Ser 400:155-163

Zamzow JP, Aumack CF, Amsler CD, McClintock JB, Amsler MO, Baker BJ (2011) Gut contents and stable isotope analyses of the Antarctic fish, Notothenia coriiceps Richardson, from two macroalgal communities. Antarct Sci 23:107-116

Zielinski K (1981) Benthic macroalgae of Admirality Bay (King George Island, South Shetland Islands) and circulation of algal matter between water and the shore. Pol Polar Res 2:71-94

Zielinski K (1990) Bottom macroalgae of the Admiralty Bay (King George Island, South Shetlands, Antarctica). Pol Polar Res 11:95-131

Submitted: January 2, 2013; Accepted: June 14, 2013

Proofs received from author(s): August 25, 2013 